\title{
Regulation of NK Cell Activation and Effector Functions by the IL-12 Family of Cytokines: The Case of IL-27
}

\author{
Norberto Walter Zwirner ${ }^{1,2 *}$ and Andrea Ziblat ${ }^{1}$ \\ 'Laboratorio de Fisiopatología de la Inmunidad Innata, Instituto de Biología y Medicina Experimental (IBYME, CONICET), \\ Ciudad de Buenos Aires, Argentina, ${ }^{2}$ Facultad de Ciencias Exactas y Naturales, Departamento de Química Biológica, \\ Universidad de Buenos Aires, Ciudad de Buenos Aires, Argentina
}

\section{OPEN ACCESS}

Edited by:

Laurent Brossay,

Brown University, USA

Reviewed by:

Francisco Borrego,

BioCruces Health Research Institute,

Spain

Jason Paul Gigley,

University of Wyoming, USA

*Correspondence:

Norberto Walter Zwirner

norzwi@gmail.com

Specialty section:

This article was submitted to

NK and Innate Lymphoid Cell Biology,

a section of the journal

Frontiers in Immunology

Received: 08 October 2016

Accepted: 06 January 2017

Published: 19 January 2017

Citation:

Zwirner NW and Ziblat A (2017)

Regulation of NK Cell Activation and

Effector Functions by the IL-12 Family

of Cytokines: The Case of IL-27.

Front. Immunol. 8:25.

doi: 10.3389/fimmu.2017.00025
Natural killer (NK) cells are characterized by their ability to detect and induce apoptosis of susceptible target cells and by secretion of immunoregulatory cytokines such as IFN- $\gamma$. Activation of these effector functions is triggered upon recognition of tumor and pathogen (mostly virus)-infected cells and because of a bidirectional cross talk that NK cells establish with other cells of myeloid origin such as dendritic cells (DC) and macrophages. A common characteristic of these myeloid cells is their ability to secrete different members of the IL-12 family of cytokines such as IL-12, IL-23, and IL-27 and cytokines such as IL-15 and IL-18. Although the effect of IL-12, IL-15, and IL-18 has been characterized, the effect of IL-23 and IL-27 on NK cells (especially human) remains ill-defined. Particularly, IL-27 is a cytokine with dual functions as it has been described as pro- and as anti-inflammatory in different experimental settings. Recent evidence indicates that this cytokine indeed promotes human NK cell activation, IFN- $\gamma$ secretion, NKp46-dependent NK cell-mediated cytotoxicity, and antibody (Ab)-dependent NK cell-mediated cytotoxicity (ADCC) against monoclonal Ab-coated tumor cells. Remarkably, IL-27 also primes NK cells for IL-18 responsiveness, enhancing these functional responses. Consequently, IL-27 acts as a pro-inflammatory cytokine that, in concert with other DC-derived cytokines, hierarchically contributes to NK cells activation and effector functions, which likely contributes to foster the adaptive immune response in different physiopathological conditions.

Keywords: NK cells, cytokines, dendritic cells, cytotoxicity, immunologic, innate immunity

\section{INTRODUCTION}

Natural killer (NK) cells constitute one of the three major lymphoid cell populations in blood. They play a protective role against viral infections and tumors, although additional evidence indicates that NK cells are also key players during immunity against other intracellular pathogens $(1,2)$. In humans, evidence about their role during viral infections came from the observation that patients with rare primary immunodeficiencies that lead to the absence of NK cells or the presence of dysfunctional NK cells display increased susceptibility to different viruses $(3,4)$. Currently, we know that the relevance of NK cells in immunity goes far beyond viral infections, being active immunoregulatory cells during infections with other pathogens, and also during autoimmune processes and in allograft rejection (1). Moreover, it has been established that NK cells are abundant in different tissues where they may exert such functions, in particular, immunosurveillance against pathogens $(5,6)$.

From a functional aspect, human and mouse NK cells share the ability to induce apoptosis of susceptible target cells through the secretory and death receptor-mediated pathways (FasL and 
TRAIL) as well as the capacity to secrete immunoregulatory cytokines (7). Nevertheless, phenotypic characterization of NK cells in both species is quite different. In mice, NK cells are mostly identified as $\mathrm{CD}^{-} \mathrm{CD}^{-} 9 \mathrm{~b}^{+}$cells, although in $\mathrm{C} 57 \mathrm{BL} / 6$ mice but they can also be characterized as $\mathrm{CD}^{-} \mathrm{CD} 161 \mathrm{~b} / \mathrm{CD} 161 \mathrm{c}^{+}$cells (better known as $\mathrm{CD}^{-} \mathrm{NK} 1.1^{+}$cells) $(2,8)$. In humans, NK cells are characterized as $\mathrm{CD}^{-}{ }^{-} \mathrm{CD} 56^{+}$cells but can be subdivided into different subpopulations based on a differential expression of CD56 and CD16 $(9,10)$. The majority of peripheral blood NK cells (about a 90\%) are $\mathrm{CD}^{-} \mathrm{CD} 56^{\mathrm{dim}} \mathrm{CD} 16^{+}$, which display a high content of perforin and granzymes and a strong cytotoxic activity, while the rest of $\mathrm{NK}$ cells in blood are $\mathrm{CD}^{-} \mathrm{CD} 56^{\text {bright }}$ CD16 ${ }^{\mathrm{dim} /-}$ and produce immunoregulatory cytokines in response to different stimuli $(11,12)$. This subpopulation of NK cells is highly abundant in second lymph organs, where they instruct dendritic cells (DC) to promote Th1- and cytotoxic CD8 T cellbiased responses, shaping in this way the adaptive immunity $(13,14)$. Some evidence suggests that $\mathrm{CD} 56^{\mathrm{bright}} \mathrm{CD} 16^{\mathrm{dim} /-}$ can differentiate into $\mathrm{CD} 56^{\mathrm{dim}} \mathrm{CD} 16^{+}$cells upon in vitro stimulation, indicating that they may constitute developmental stages of fully mature CD56 ${ }^{\mathrm{dim}} \mathrm{CD} 16^{+} \mathrm{NK}$ cells (15-17). NK cell subpopulations also express different chemokine receptors involved in their homing to different anatomical niches $(5,18)$.

Recently, identification of innate immune lymphoid cell populations (ILC), especially in mucosal sites, led to a reclassification of NK cells as members of this extended family of cells of the innate immune response (19-22). ILC contribute to tissue homeostasis, and they seem to be important players of immunity in mucosal sites. Three groups of ILC populations have been described (ILC1, ILC2, and ILC3), which differ in their transcriptional, phenotypic, and transcriptional signatures, respectively $(19,21,22)$. Moreover, ILC phenotype and function mirrors the phenotype and function of T cells, indicating that innate immune cells display a similar functional compartmentalization as occurs with adaptive immune cells. NK cells have been classified as a subgroup of ILC1, suggesting that they could be some sort of ancestors or innate counterparts of $\mathrm{T}$ helper 1 and cytotoxic T lymphocyte (CTL) cells $(19,21,22)$. Although all ILC1 express T-bet, respond to IL-12 and IL-15 and share the ability to produce IFN- $\gamma$, only NK cells express EOMES, which differentiates them from other ILC1 populations $(19,21,22)$.

A vast array of surface receptors confer NK cells the ability to sense their environment. Direct recognition of target cells through inhibitory and activating receptors is a critical event that determines activation of NK cell-mediated cytotoxicity against susceptible cells (virus-infected or neoplastic cells), preserving healthy cells from such response (7). Many receptors that recognize discrete ligands expressed on target cells and that trigger NK cell activation or promote inhibition of NK cell-mediated effector functions have been identified and cloned $(2,10)$. The better characterized receptors that regulate target cell recognition and activation by NK cells are CD16 or FcR $\gamma$ III [which mediates antibody $(\mathrm{Ab})$-recognition of target cells and triggers $\mathrm{Ab}$-dependent cell-mediated cytotoxicity or ADCC], CD314 or NKG2D, the natural cytotoxicity receptors CD335 (NKp46), CD336 (NKp44) and CD337 (NKp30), CD226 (DNAM-1), CD244 (2B4), members of the CD158 or killer immunoglobulin-like receptor (KIR) family that carry a short cytoplasmic tail (KIR2DS and KIR3DS) and CD94/NKG2C, among others (2, 10, 23). Conversely, inhibitory receptors that preclude NK cell activation are members of the CD158 or KIR family that carry a long cytoplasmic tail (KIR2DL and KIR3DL), CD94/NKG2A, TIGIT, and CD85j (ILT-2, LILRB1, or LIR-1), among others $(2,10,23)$.

Natural killer cells not only sense and respond to ligands expressed on the cell surface of target cells. Instead, functional response of NK cells also depends on recognition of soluble factors such as pro-inflammatory cytokines (24). Nonetheless, other soluble factors also exert immunoregulatory functions on these cells. We and others (25-30) observed that NK cells express endosomal toll-like receptors (TLRs) and respond to specific agonists. In particular, human NK cells express functional TLR3, TLR7, and TLR9, and stimulation of NK cells with their agonists triggers IFN- $\gamma$ secretion only in the presence of suboptimal concentrations of IL-12 or IFN- $\alpha$ but not IL-15 (25). This effect was further potentiated by co-engagement of NKG2D, one of the major cell surface receptors involved in recognition and elimination of tumor cells by NK cells, but TLR agonists do not seem to exert immunoregulatory effects on NKG2D-dependent NK cell-mediated cytotoxicity (5). Therefore, NK cells can sense and integrate signals derived from their surrounding environment, and that are detected by different categories of receptors.

Biological functions of NK cells are tightly regulated during their interaction with DC as a consequence of which NK cells promote maturation of DC and become activated by cell surface receptors such as NKp30 (31) and DNAM-1 (32) and cytokines such as IL-12, IL-15, and IL-18 (9, 13, 31-35). Remarkably, the consequences of this interaction are not only manifested in NK cells but also impact on the adaptive immunity as NK cells promote maturation of DC and instruct them to shape T cell activation toward Th1- and CTL-mediated responses (13, 14, 31, 33).

In this context, an integral analysis of factors that regulate NK cell effector functions may contribute to the development of novel strategies to improve immunosurveillance and promote a sustained tumoricidal capacity of NK cells (7). Therefore, the focus of our laboratory has been the investigation of how NK cells sense their environment and unravel novel factors that affect their phenotype and functions.

\section{REGULATION OF NK CELL ACTIVATION AND EFFECTOR FUNCTIONS BY IL-27}

IL-12 is the first described member of an extended family of cytokines produced mostly by myeloid cells (DC and macrophages) in response to infectious agents and other insults (36). IL-12 promotes the generation of Th1, IFN- $\gamma$-producing cells during naive $\mathrm{CD} 4^{+} \mathrm{T}$ cell activation (37). Also, IL-12 produced by macrophages triggers NK cell-mediated IFN- $\gamma$ production during infection with intracellular parasites (38) and contributes to protection during acute infection (39). These findings unraveled the existence of a cytokine axis in which myeloid cell-derived IL-12 triggers lymphoid cell-derived IFN- $\gamma$ production and contributes to resistance to infection.

Members of the IL-12 family of heterodimeric cytokines share protein subunits and receptor chains. IL-12 is composed 
by two subunits, namely, p35 and p40, and is recognized by a heterodimeric receptor composed of two chains IL-12R $\beta 1$ and IL-12R $\beta 2$ (36). Signaling through this receptor activates mainly STAT4, activates T-bet, and leads to IFN- $\gamma$ production in NK and $\mathrm{T}$ cells, thus mediating pro-inflammatory effects (40-42). Since naïve $\mathrm{T}$ cells do not express IL-12R $\beta 2$, IL-12 alone does not seem to be sufficient to guide $\mathrm{T}$ cell activation toward Th1 cells (43). A similar effect was described for IFN- $\gamma$ production by human and mouse NK cells $(25,44-46)$, suggesting that IL-12 requires a cooperation with other factors to properly exert its effects on NK and T cell-derived IFN- $\gamma$ production. IL-12 also enhances NK cell-mediated cytotoxicity against different target cells, affects expression of some cell surface receptors involved in target cell recognition (47-49), and, more recently, IL-12 has also been involved in the generation of memory-like NK cells $(50,51)$. IL-12 is secreted by DC and macrophages and has been shown to be a major player of a bidirectional cross talk that they establish with NK or T cells (36). Also, as a consequence of their cross talk with macrophages, NK cells can stimulate production of nitric oxide (NO) due to upregulation of inducible NO synthase (52). In addition, as a consequence of their cross talk with DC, NK cells can promote upregulation of costimulatory molecules such as CD86 (53).

Other members of the IL-12 family of cytokines are IL-23, IL-27, and IL-35 $(36,54)$ which, as mentioned, are heterodimeric proteins that share not only one subunit with another member of the family but also signal through heterodimeric receptors with shared subunits $(54,55)$. As with IL-12, macrophages and DC can produce IL-23 and IL-27 upon sensing pathogens or their products (56-59). IL-23 is composed by one subunit shared with IL-12 (p40) that is associated with the p19 subunit to constitute the active form of IL-23. This cytokine signals through a heterodimeric receptor composed of IL-12R $\beta 1$ and IL-23R, which activates Jak2/Tyk2, STAT1/STAT3/STAT4/STAT5 (60). IL-23 activates NK cells and in this way, contributes to the antitumor immune response $(61,62)$. Nevertheless, other authors failed to demonstrate an effect of IL-23 on NK cells $(63,64)$, making the effects of this cytokine on NK cells an open question that warrants further investigation.

IL-27, in turn, is a heterodimeric cytokine composed by the EBI3 and p28 subunits that signals through a heterodimeric receptor composed by the WSX-1 and CD130/gp130 chains $(54,55,65,66)$. As with other members of this familty of cytokines, IL-27 is produced mainly by DC and macrophages upon microbial insults (55). Paradoxically, IL-27 displays proand anti-inflammatory functions due to activation of STAT1 and STAT3, respectively (36), but its pro-inflammatory effects depend on induction of T-bet and IL-12R $\beta 2$ expression (67-69). In line with a dual role of IL-27, it has been shown that this cytokine prevents tissue damage induced by excessive inflammation $(54,70)$. The effect of IL-27 on NK cells and their ability to control tumor growth have been described in some mouse models $(63,70-76)$, while in other tumor models, an effect of IL-27 on NK cells was not observed (77). Therefore, the effects of IL-27 on mouse NK cells might be tumor-type dependent. In humans, it was reported that IL-27 can costimulate NK cells for IFN- $\gamma$ gene expression (78), while we observed that mature
DC secrete IL-27 and that this cytokine contributes to NK cell activation and effector functions (79). Indeed, IL-27 can directly trigger IFN- $\gamma$ secretion through activation of STAT1 and promote activation of NK cells (upregulation of CD25 and CD69). IL-27 also promotes upregulation of NKp46 and subsequent NKp46-dependent NK cell-mediated cytotoxicity against target cells that are otherwise resistant to NK cell-mediated cytotoxicity, through the secretory pathway and TRAIL (79). IL-27 also potentiates ADCC induced by therapeutic monoclonal antibodies such as rituximab, trastuzumab, and cetuximab, suggesting that IL-27 may be helpful as adjuvant during immunotherapy in human patients (79). The effects of IL-27 on NK cells are summarized in Figure 1.

\section{COOPERATION BETWEEN CYTOKINES FOR NK CELL STIMULATION: THE CASE OF IL-27 AND IL-18}

Cooperative effect of cytokines, in particular those secreted by DC and macrophages, has been described for many of them and reviewed elsewhere (24). Briefly, cooperative effects of IL-12 and IL-2 or IL-15 (80, 81), IL-2 and IL-15 (82), IL-12

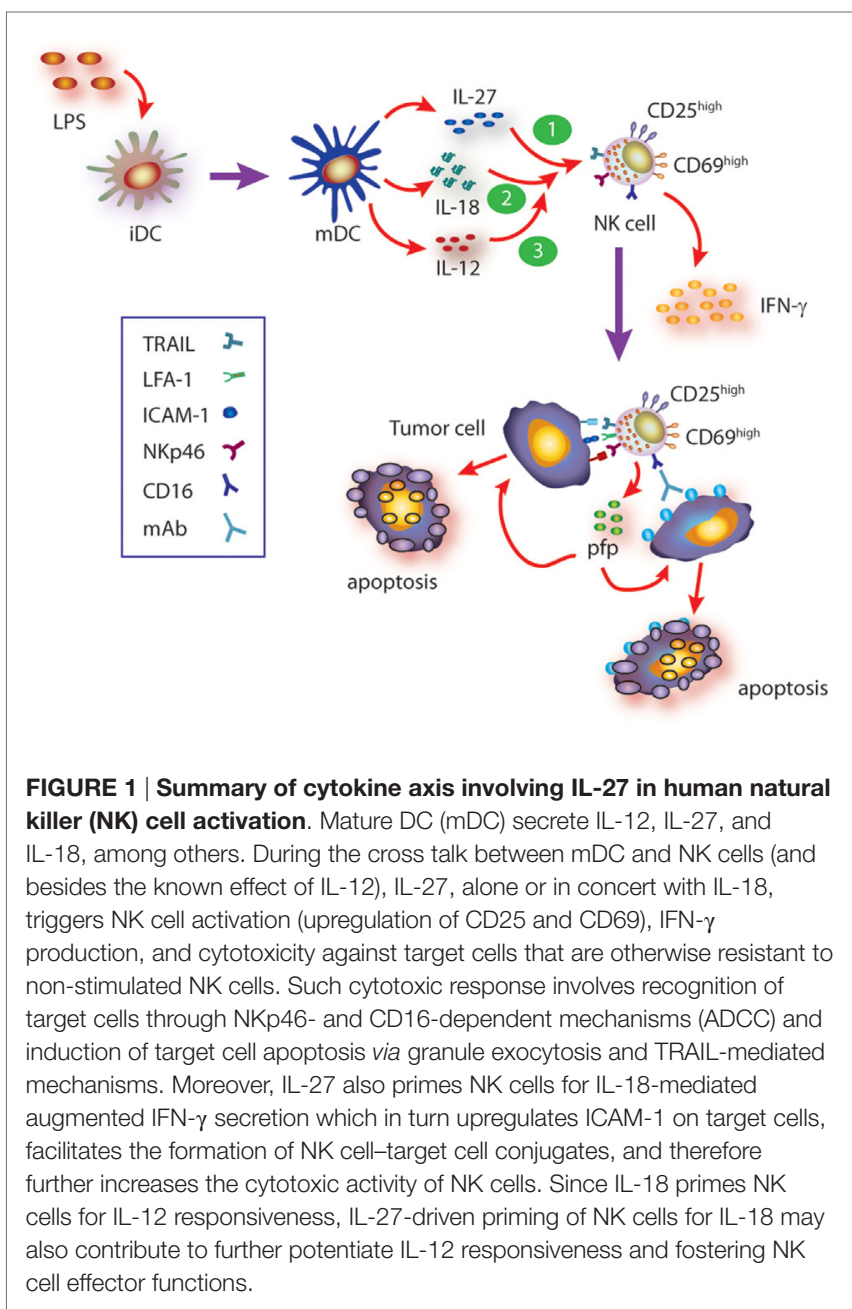


and IL-18 $(81,83-85)$ for NK cell activation, IFN- $\gamma$ production, and cytotoxicity have been described. In most cases, underlying mechanisms of cytokine cooperation for NK cell activation remain ill-defined. IL-18 belongs to the IL-1 superfamily and has the peculiarity of having a critical effect on NK cells (86). IL-18 seems to play a major role as "cooperating cytokine" for NK cell activation and elicitation of effector functions $(87,88)$. Accordingly, NK cells from IL- $18^{-1-}$ mice display a deep impaired immune response against tumors and cannot be properly stimulated in vivo with IL-12 to secrete IFN- $\gamma$ (89). These and other experimental results led to the notion that IL-18 actually primes NK cells to become responsive to IL-12 (89-91). Remarkably, we demonstrated that IL-27 also primes NK cells but for IL-18-mediated IFN- $\gamma$ secretion inducing upregulation of T-bet expression in NK cells (79). T-bet is a critical transcription factor that regulates IFN- $\gamma$ production $(92,93)$ by promoting IFN- $\gamma$ gene transcription (94). Moreover, cooperation between IL-27 and IL-18 enhances NK cell-mediated cytotoxicity through the secretory pathway and TRAIL and involves NK cell-derived IFN- $\gamma$. This is because IFN- $\gamma$ secretion during effector-target cell contact increases the percentage of ICAM-1 $1^{+}$target cells that in turn facilitates the formation of NK cell-target cell conjugates and delivery of the cytotoxic hit (95). These effects are summarized in Figure 1.

As DC and macrophages stimulated with microbial products or tumor cells can secrete IL-12, IL-18, and IL-27 $(36,73)$, it is possible that stimulatory effects of IL-27 may occur when DC or macrophages secrete this cytokine and establish a bidirectional cross talk with NK cells. During this cross talk, IL-27 may prime NK cells for IL-18 responsiveness, while IL-18 secreted at the synaptic cleft between NK cells and DC (91) may in turn prime NK cells for IL-12 responsiveness (90). Although a kinetic analysis of the production of these cytokines needs to be performed to establish the temporal relationship in their secretion, the cooperation between IL-27 and IL-18 that we described unravels the existence of a hierarchical cytokine network that is relevant during DC-NK cell cross talk that generates fully functional NK cells. In line with this hierarchical cytokine network in NK cell activation is the fact that IL-27 can initiate Th1 development by naïve $\mathrm{T}$ cells by promoting activation of STAT1 and STAT3, expression of T-bet, repression of GATA3 (involved in Th2 differentiation), and production of IL-12R $\beta 2$ chain $(67,68,96,97)$. These changes in CD4 T cells during activation confer them the ability to sense DC-derived IL-12 and consequently follow the path of Th1 differentiation, leading to secretion of IFN- $\gamma$.

\section{REFERENCES}

1. Newman KC, Riley EM. Whatever turns you on: accessory-cell-dependent activation of NK cells by pathogens. Nat Rev Immunol (2007) 7(4):279-91. doi:10.1038/nri2057

2. Lanier LL. Up on the tightrope: natural killer cell activation and inhibition. Nat Immunol (2008) 9(5):495-502. doi:10.1038/ni1581

3. Orange JS, Brodeur SR, Jain A, Bonilla FA, Schneider LC, Kretschmer $\mathrm{R}$, et al. Deficient natural killer cell cytotoxicity in patients with IKKgamma/NEMO mutations. J Clin Invest (2002) 109(11):1501-9. doi:10.1172/ JCI14858
Collectively, the cytokine axis composed of IL-27/IL-18/IL-12 is indeed involved in optimal NK cell activation and in skewing CD4 T cell responses through a cross talk between these lymphoid cells (NK cells and T cells) and myeloid cells (DC), representing an important link between innate and adaptive immunity.

\section{CONCLUDING REMARKS}

Natural killer cells are currently viewed not only as cytotoxic cells but also as strong producers of immunoregulatory cytokines, in particular, IFN- $\gamma$. They belong to the family of ILC, and their effector functions are tightly regulated by interaction with DC and other cells of myeloid lineage, which secrete cytokines with NK cell-stimulating activity. IL-12 is one of the most relevant cytokines produced by myeloid cells that promote NK cell activation. The discovery of other members of the IL- 12 family of cytokines, such as IL-23 and IL-27, and exploration of cooperation between cytokines for NK cell activation have established that NK cells also become activated by IL-27. Interestingly, IL-27 not only exerts direct effects on NK cells but also primes them for IL-18-responsiveness, which unveils another aspect of the intricate cytokine network that regulates NK cell biological functions and that further demonstrates a hierarchical effect of different cytokines on these cells. Consequently, NK cells display the ability to integrate multiple signals from their environment and adjust their effector functions accordingly, probably to optimize the magnitude of their response to pathogens and tumor cells and shape adaptive immunity in different physiopathological conditions.

\section{AUTHOR CONTRIBUTIONS}

$\mathrm{NZ}$ designed and wrote the review and prepared the figures. AZ revised the manuscript and figures.

\section{ACKNOWLEDGMENTS}

The authors would like to thank to past and current lab members. This work was supported by grants from the National Agency for Promotion of Scienceand Technology from Argentina (ANPCYT), the National Research Council of Argentina (CONICET), and the University of Buenos Aires (UBA), all to NZ. The authors also thank to Fundación Williams and Fundación René Barón for providing financial assistance (donations) to their laboratory. NZ is a member of the Researcher Career of CONICET and professor at UBA. AZ is a postdoctoral fellow of CONICET.

4. Orange JS. Unraveling human natural killer cell deficiency. J Clin Invest (2012) 122(3):798-801. doi:10.1172/JCI62620

5. Carrega P, Ferlazzo G. Natural killer cell distribution and trafficking in human tissues. Front Immunol (2012) 3:347. doi:10.3389/fimmu.2012.00347

6. Melsen JE, Lugthart G, Lankester AC, Schilham MV. Human circulating and tissue-resident CD56(bright) natural killer cell populations. Front Immunol (2016) 7:262. doi:10.3389/fimmu.2016.00262

7. Morvan MG, Lanier LL. NK cells and cancer: you can teach innate cells new tricks. Nat Rev Cancer (2016) 16(1):7-19. doi:10.1038/nrc.2015.5

8. Geiger TL, Sun JC. Development and maturation of natural killer cells. Curr Opin Immunol (2016) 39:82-9. doi:10.1016/j.coi.2016.01.007 
9. Moretta A. Natural killer cells and dendritic cells: rendezvous in abused tissues. Nat Rev Immunol (2002) 2(12):957-64. doi:10.1038/nri956

10. Moretta A, Marcenaro E, Parolini S, Ferlazzo G, Moretta L. NK cells at the interface between innate and adaptive immunity. Cell Death Differ (2008) 15(2):226-33. doi:10.1038/sj.cdd.4402170

11. Caligiuri MA. Human natural killer cells. Blood (2008) 112(3):461-9. doi:10.1182/blood-2007-09-077438

12. Strowig T, Brilot F, Munz C. Noncytotoxic functions of NK cells: direct pathogen restriction and assistance to adaptive immunity. J Immunol (2008) 180(12):7785-91. doi:10.4049/jimmunol.180.12.7785

13. Ferlazzo G, Pack M, Thomas D, Paludan C, Schmid D, Strowig T, et al. Distinct roles of IL-12 and IL-15 in human natural killer cell activation by dendritic cells from secondary lymphoid organs. Proc Natl Acad Sci U S A (2004) 101(47):16606-11. doi:10.1073/pnas.0407522101

14. Ferlazzo G, Thomas D, Lin SL, Goodman K, Morandi B, Muller WA, et al. The abundant NK cells in human secondary lymphoid tissues require activation to express killer cell Ig-like receptors and become cytolytic. J Immunol (2004) 172(3):1455-62. doi:10.4049/jimmunol.172.3.1455

15. Chan A, Hong DL, Atzberger A, Kollnberger S, Filer AD, Buckley CD, et al. CD56 $6^{\text {bright }}$ human NK cells differentiate into CD56 $6^{\text {dim }}$ cells: role of contact with peripheral fibroblasts. JImmunol (2007) 179(1):89-94. doi:10.4049/ jimmunol.179.1.89

16. Romagnani C, Juelke K, Falco M, Morandi B, D’Agostino A, Costa R, et al. $\mathrm{CD} 56^{\text {bright }} \mathrm{CD} 16^{-}$killer Ig-like receptor- NK cells display longer telomeres and acquire features of CD56 ${ }^{\mathrm{dim}} \mathrm{NK}$ cells upon activation. J Immunol (2007) 178(8):4947-55. doi:10.4049/jimmunol.178.8.4947

17. Luetke-Eversloh M, Killig M, Romagnani C. Signatures of human NK cell development and terminal differentiation. Front Immunol (2013) 4:499. doi:10.3389/fimmu.2013.00499

18. Campbell JJ, Qin S, Unutmaz D, Soler D, Murphy KE, Hodge MR, et al. Unique subpopulations of $\mathrm{CD}^{+} 6^{+} \mathrm{NK}$ and NK-T peripheral blood lymphocytes identified by chemokine receptor expression repertoire. JImmunol (2001) 166(11):6477-82. doi:10.4049/jimmunol.166.11.6477

19. Cella M, Miller H, Song C. Beyond NK cells: the expanding universe of innate lymphoid cells. Front Immunol (2014) 5:282. doi:10.3389/fimmu.2014.00282

20. Spits H, Artis D, Colonna M, Diefenbach A, Di Santo JP, Eberl G, et al. Innate lymphoid cells - a proposal for uniform nomenclature. Nat Rev Immunol (2013) 13(2):145-9. doi:10.1038/nri3365

21. McKenzie AN, Spits H, Eberl G. Innate lymphoid cells in inflammation and immunity. Immunity (2014) 41(3):366-74. doi:10.1016/j.immuni.2014.09.006

22. Diefenbach A, Colonna M, Koyasu S. Development, differentiation, and diversity of innate lymphoid cells. Immunity (2014) 41(3):354-65. doi:10.1016/j. immuni.2014.09.005

23. Bartel Y, Bauer B, Steinle A. Modulation of NK cell function by genetically coupled C-type lectin-like receptor/ligand pairs encoded in the human natural killer gene complex. Front Immunol (2013) 4:362. doi:10.3389/ fimmu.2013.00362

24. Zwirner NW, Domaica CI. Cytokine regulation of natural killer cell effector functions. Biofactors (2010) 36(4):274-88. doi:10.1002/biof.107

25. Girart MV, Fuertes MB, Domaica CI, Rossi LE, Zwirner NW. Engagement of TLR3, TLR7, and NKG2D regulate IFN-gamma secretion but not NKG2Dmediated cytotoxicity by human NK cells stimulated with suboptimal doses of IL-12. J Immunol (2007) 179(6):3472-9. doi:10.4049/jimmunol. 179.6.3472

26. Chalifour A, Jeannin P, Gauchat JF, Blaecke A, Malissard M, N'Guyen T, et al. Direct bacterial protein PAMP recognition by human NK cells involves TLRs and triggers alpha-defensin production. Blood (2004) 104(6):1778-83. doi:10.1182/blood-2003-08-2820

27. Hart OM, Athie-Morales V, O'Connor GM, Gardiner CM. TLR7/8mediated activation of human NK cells results in accessory cell-dependent IFN-gamma production. J Immunol (2005) 175(3):1636-42. doi:10.4049/ jimmunol.175.3.1636

28. Sivori S, Falco M, Della Chiesa M, Carlomagno S, Vitale M, Moretta L, et al. CpG and double-stranded RNA trigger human NK cells by toll-like receptors: induction of cytokine release and cytotoxicity against tumors and dendritic cells. Proc Natl Acad Sci U S A (2004) 101(27):10116-21. doi:10.1073/ pnas.0403744101

29. Gorski KS, Waller EL, Bjornton-Severson J, Hanten JA, Riter CL, Kieper WC, et al. Distinct indirect pathways govern human NK-cell activation by TLR-7 and TLR-8 agonists. Int Immunol (2006) 18(7):1115-26. doi:10.1093/intimm/ dxl046

30. Schmidt KN, Leung B, Kwong M, Zarember KA, Satyal S, Navas TA, et al. APC-independent activation of NK cells by the toll-like receptor 3 agonist double-stranded RNA. JImmunol (2004) 172(1):138-43. doi:10.4049/ jimmunol.172.1.138

31. Ferlazzo G, Tsang ML, Moretta L, Melioli G, Steinman RM, Munz C. Human dendritic cells activate resting natural killer (NK) cells and are recognized via the NKp30 receptor by activated NK cells. J Exp Med (2002) 195(3):343-51. doi:10.1084/jem.20011149

32. Pende D, Castriconi R, Romagnani P, Spaggiari GM, Marcenaro S, Dondero A, et al. Expression of the DNAM-1 ligands, Nectin-2 (CD112) and poliovirus receptor (CD155), on dendritic cells: relevance for natural killer-dendritic cell interaction. Blood (2006) 107(5):2030-6. doi:10.1182/ blood-2005-07-2696

33. Martin-Fontecha A, Thomsen LL, Brett S, Gerard C, Lipp M, Lanzavecchia A, et al. Induced recruitment of NK cells to lymph nodes provides IFNgamma for T(H)1 priming. Nat Immunol (2004) 5(12):1260-5. doi:10.1038/ ni1138

34. Spaggiari GM, Carosio R, Pende D, Marcenaro S, Rivera P, Zocchi MR, et al. NK cell-mediated lysis of autologous antigen-presenting cells is triggered by the engagement of the phosphatidylinositol 3-kinase upon ligation of the natural cytotoxicity receptors NKp30 and NKp46. Eur J Immunol (2001) 31(6):1656-65. doi:10.1002/1521-4141(200106)31:6<1656: AID-IMMU1656>3.0.CO;2-V

35. Walzer T, Dalod M, Robbins SH, Zitvogel L, Vivier E. Natural-killer cells and dendritic cells: "l'union fait la force". Blood (2005) 106(7):2252-8. doi:10.1182/ blood-2005-03-1154

36. Vignali DA, Kuchroo VK. IL-12 family cytokines: immunological playmakers. Nat Immunol (2012) 13(8):722-8. doi:10.1038/ni.2366

37. Seder RA, Gazzinelli R, Sher A, Paul WE. Interleukin 12 acts directly on $\mathrm{CD} 4^{+}$ $\mathrm{T}$ cells to enhance priming for interferon gamma production and diminishes interleukin 4 inhibition of such priming. Proc Natl Acad Sci U S A (1993) 90(21):10188-92. doi:10.1073/pnas.90.21.10188

38. Gazzinelli RT, Hieny S, Wynn TA, Wolf S, Sher A. Interleukin 12 is required for the T-lymphocyte-independent induction of interferon gamma by an intracellular parasite and induces resistance in T-cell-deficient hosts. Proc Natl Acad Sci U S A (1993) 90(13):6115-9. doi:10.1073/pnas.90. 13.6115

39. Gazzinelli RT, Wysocka M, Hayashi S, Denkers EY, Hieny S, Caspar P, et al. Parasite-induced IL-12 stimulates early IFN-gamma synthesis and resistance during acute infection with Toxoplasma gondii. J Immunol (1994) 153(6):2533-43.

40. Jacobson NG, Szabo SJ, Weber-Nordt RM, Zhong Z, Schreiber RD, Darnell JE Jr, et al. Interleukin 12 signaling in T helper type 1 (Th1) cells involves tyrosine phosphorylation of signal transducer and activator of transcription (Stat)3 and Stat4. J Exp Med (1995) 181(5):1755-62. doi:10.1084/jem.181. 5.1755

41. Thierfelder WE, van Deursen JM, Yamamoto K, Tripp RA, Sarawar SR, Carson RT, et al. Requirement for Stat 4 in interleukin-12-mediated responses of natural killer and T cells. Nature (1996) 382(6587):171-4. doi:10.1038/ 382171a0

42. Kaplan MH, Sun YL, Hoey T, Grusby MJ. Impaired IL-12 responses and enhanced development of Th2 cells in Stat4-deficient mice. Nature (1996) 382(6587):174-7. doi:10.1038/382174a0

43. Szabo SJ, Dighe AS, Gubler U, Murphy KM. Regulation of the interleukin (IL)-12R beta 2 subunit expression in developing T helper 1 (Th1) and Th2 cells. J Exp Med (1997) 185(5):817-24. doi:10.1084/jem.185.5.817

44. Nguyen KB, Salazar-Mather TP, Dalod MY, Van Deusen JB, Wei XQ, Liew FY, et al. Coordinated and distinct roles for IFN-alpha beta, IL-12, and IL-15 regulation of NK cell responses to viral infection. J Immunol (2002) 169(8):4279-87. doi:10.4049/jimmunol.169.8.4279

45. Andoniou CE, van Dommelen SL, Voigt V, Andrews DM, Brizard G, AsselinPaturel C, et al. Interaction between conventional dendritic cells and natural killer cells is integral to the activation of effective antiviral immunity. Nat Immunol (2005) 6(10):1011-9. doi:10.1038/ni1244

46. Loza MJ, Perussia B. The IL-12 signature: NK cell terminal CD56 ${ }^{\text {thigh }}$ stage and effector functions. J Immunol (2004) 172(1):88-96. doi:10.4049/ jimmunol.172.1.88 
47. Hashimoto W, Osaki T, Okamura H, Robbins PD, Kurimoto M, Nagata S, et al. Differential antitumor effects of administration of recombinant IL-18 or recombinant IL-12 are mediated primarily by Fas-Fas ligand- and perforininduced tumor apoptosis, respectively. J Immunol (1999) 163(2):583-9.

48. Kodama T, Takeda K, Shimozato O, Hayakawa Y, Atsuta M, Kobayashi K, et al. Perforin-dependent NK cell cytotoxicity is sufficient for anti-metastatic effect of IL-12. Eur J Immunol (1999) 29(4):1390-6. doi:10.1002/ (SICI)1521-4141(199904)29:04<1390:AID-IMMU1390>3.0.CO;2-C

49. Orange JS, Wang B, Terhorst C, Biron CA. Requirement for natural killer cell-produced interferon gamma in defense against murine cytomegalovirus infection and enhancement of this defense pathway by interleukin 12 administration. J Exp Med (1995) 182(4):1045-56. doi:10.1084/jem.182.4.1045

50. Cooper MA, Elliott JM, Keyel PA, Yang L, Carrero JA, Yokoyama WM. Cytokine-induced memory-like natural killer cells. Proc Natl Acad Sci U S A (2009) 106(6):1915-9. doi:10.1073/pnas.0813192106

51. O'Sullivan TE, Sun JC, Lanier LL. Natural killer cell memory. Immunity (2015) 43(4):634-45. doi:10.1016/j.immuni.2015.09.013

52. Yang J, Kawamura I, Zhu H, Mitsuyama M. Involvement of natural killer cells in nitric oxide production by spleen cells after stimulation with Mycobacterium bovis BCG. Study of the mechanism of the different abilities of viable and killed BCG. J Immunol (1995) 155(12):5728-35.

53. Mailliard RB, Son YI, Redlinger R, Coates PT, Giermasz A, Morel PA, et al. Dendritic cells mediate NK cell help for Th1 and CTL responses: two-signal requirement for the induction of NK cell helper function. J Immunol (2003) 171(5):2366-73. doi:10.4049/jimmunol.171.5.2366

54. Kastelein RA, Hunter CA, Cua DJ. Discovery and biology of IL-23 and IL-27: related but functionally distinct regulators of inflammation. Annu Rev Immunol (2007) 25:221-42. doi:10.1146/annurev.immunol.22.012703. 104758

55. Pflanz S, Timans JC, Cheung J, Rosales R, Kanzler H, Gilbert J, et al. IL-27, a heterodimeric cytokine composed of EBI3 and p28 protein, induces proliferation of naive CD4(+) T cells. Immunity (2002) 16(6):779-90. doi:10.1016/ S1074-7613(02)00324-2

56. de Groot R, van Beelen AJ, Bakdash G, Taanman-Kueter EW, de Jong EC, Kapsenberg ML. Viral dsRNA-activated human dendritic cells produce IL-27, which selectively promotes cytotoxicity in naive $\mathrm{CD}^{+} \mathrm{T}$ cells. J Leukoc Biol (2012) 92(3):605-10. doi:10.1189/jlb.0112045

57. Molle C, Nguyen M, Flamand V, Renneson J, Trottein F, De Wit D, et al. IL-27 synthesis induced by TLR ligation critically depends on IFN regulatory factor 3. J Immunol (2007) 178(12):7607-15. doi:10.4049/jimmunol.178.12.7607

58. Iyer SS, Ghaffari AA, Cheng G. Lipopolysaccharide-mediated IL-10 transcriptional regulation requires sequential induction of type I IFNs and IL-27 in macrophages. J Immunol (2010) 185(11):6599-607. doi:10.4049/ jimmunol.1002041

59. Pirhonen J, Siren J, Julkunen I, Matikainen S. IFN-alpha regulates toll-like receptor-mediated IL-27 gene expression in human macrophages. J Leukoc Biol (2007) 82(5):1185-92. doi:10.1189/jlb.0307157

60. Parham C, Chirica M, Timans J, Vaisberg E, Travis M, Cheung J, et al. A receptor for the heterodimeric cytokine IL-23 is composed of IL-12Rbetal and a novel cytokine receptor subunit, IL-23R. J Immunol (2002) 168(11):5699-708. doi:10.4049/jimmunol.168.11.5699

61. Hu J, Yuan X, Belladonna ML, Ong JM, Wachsmann-Hogiu S, Farkas DL, et al. Induction of potent antitumor immunity by intratumoral injection of interleukin 23-transduced dendritic cells. Cancer Res (2006) 66(17):8887-96. doi:10.1158/0008-5472.CAN-05-3448

62. Kaiga T, Sato M, Kaneda H, Iwakura Y, Takayama T, Tahara H. Systemic administration of IL-23 induces potent antitumor immunity primarily mediated through Th1-type response in association with the endogenously expressed IL-12. J Immunol (2007) 178(12):7571-80. doi:10.4049/jimmunol. 178.12.7571

63. Hu P, Hu HD, Chen M, Peng ML, Tang L, Tang KF, et al. Expression of interleukins-23 and 27 leads to successful gene therapy of hepatocellular carcinoma. Mol Immunol (2009) 46(8-9):1654-62. doi:10.1016/j.molimm.2009. 02.025

64. Lo CH, Lee SC, Wu PY, Pan WY, Su J, Cheng CW, et al. Antitumor and antimetastatic activity of IL-23. J Immunol (2003) 171(2):600-7. doi:10.4049/ jimmunol.171.2.600

65. Yoshida H, Hunter CA. The immunobiology of interleukin-27. Annu Rev Immunol (2015) 33:417-43. doi:10.1146/annurev-immunol-032414-112134
66. Aparicio-Siegmund S, Garbers C. The biology of interleukin-27 reveals unique pro- and anti-inflammatory functions in immunity. Cytokine Growth Factor Rev (2015) 26(5):579-86. doi:10.1016/j.cytogfr.2015.07.008

67. Takeda A, Hamano S, Yamanaka A, Hanada T, Ishibashi T, Mak TW, et al. Role of IL-27/WSX-1 signaling for induction of T-bet through activation of STAT1 during initial Th1 commitment. J Immunol (2003) 170(10):4886-90. doi:10.4049/jimmunol.170.10.4886

68. Lucas S, Ghilardi N, Li J, de Sauvage FJ. IL-27 regulates IL-12 responsiveness of naive $\mathrm{CD}^{+} \mathrm{T}$ cells through Stat1-dependent and -independent mechanisms. Proc Natl Acad Sci U S A (2003) 100(25):15047-52. doi:10.1073/ pnas. 2536517100

69. Hibbert L, Pflanz S, De Waal Malefyt R, Kastelein RA. IL-27 and IFNalpha signal via Stat 1 and Stat 3 and induce T-Bet and IL-12Rbeta2 in naive T cells. J Interferon Cytokine Res (2003) 23(9):513-22. doi:10.1089/ 10799900360708632

70. Wei J, Xia S, Sun H, Zhang S, Wang J, Zhao H, et al. Critical role of dendritic cell-derived IL-27 in antitumor immunity through regulating the recruitment and activation of NK and NKT cells. J Immunol (2013) 191(1):500-8. doi:10.4049/jimmunol.1300328

71. Oniki S, Nagai H, Horikawa T, Furukawa J, Belladonna ML, Yoshimoto T, et al. Interleukin-23 and interleukin-27 exert quite different antitumor and vaccine effects on poorly immunogenic melanoma. Cancer Res (2006) 66(12):6395-404. doi:10.1158/0008-5472.CAN-05-4087

72. Chiyo M, Shimozato O, Yu L, Kawamura K, Iizasa T, Fujisawa T, et al. Expression of IL-27 in murine carcinoma cells produces antitumor effects and induces protective immunity in inoculated host animals. Int J Cancer (2005) 115(3):437-42. doi:10.1002/ijc. 20848

73. Cocco C, Pistoia V, Airoldi I. Anti-leukemic properties of IL-12, IL-23 and IL-27: differences and similarities in the control of pediatric B acute lymphoblastic leukemia. Crit Rev Oncol Hematol (2012) 83(3):310-8. doi:10.1016/j. critrevonc.2011.11.006

74. Liu L, Wang S, Shan B, Shao L, Sato A, Kawamura K, et al. IL-27-mediated activation of natural killer cells and inflammation produced antitumour effects for human oesophageal carcinoma cells. Scand J Immunol (2008) 68(1):22-9. doi:10.1111/j.1365-3083.2008.02111.x

75. Liu Z, Liu JQ, Talebian F, Wu LC, Li S, Bai XF. IL-27 enhances the survival of tumor antigen-specific $\mathrm{CD} 8^{+} \mathrm{T}$ cells and programs them into IL-10-producing, memory precursor-like effector cells. Eur J Immunol (2013) 43(2):468-79. doi:10.1002/eji.201242930

76. Matsui M, Kishida T, Nakano H, Yoshimoto K, Shin-Ya M, Shimada T, et al. Interleukin-27 activates natural killer cells and suppresses NK-resistant head and neck squamous cell carcinoma through inducing antibody-dependent cellular cytotoxicity. Cancer Res (2009) 69(6):2523-30. doi:10.1158/00085472.CAN-08-2793

77. Salcedo R, Stauffer JK, Lincoln E, Back TC, Hixon JA, Hahn C, et al. IL-27 mediates complete regression of orthotopic primary and metastatic murine neuroblastoma tumors: role for CD8 ${ }^{+}$T cells. J Immunol (2004) 173(12):717082. doi:10.4049/jimmunol.173.12.7170

78. Laroni A, Gandhi R, Beynon V, Weiner HL. IL-27 imparts immunoregulatory function to human NK cell subsets. PLoS One (2011) 6(10):e26173. doi:10.1371/journal.pone.0026173

79. Ziblat A, Domaica CI, Spallanzani RG, Iraolagoitia XL, Rossi LE, Avila DE, et al. IL-27 stimulates human NK-cell effector functions and primes NK cells for IL-18 responsiveness. Eur J Immunol (2015) 45(1):192-202. doi:10.1002/ eji.201444699

80. Ross ME, Caligiuri MA. Cytokine-induced apoptosis of human natural killer cells identifies a novel mechanism to regulate the innate immune response. Blood (1997) 89(3):910-8.

81. Fehniger TA, Shah MH, Turner MJ, VanDeusen JB, Whitman SP, Cooper MA, et al. Differential cytokine and chemokine gene expression by human NK cells following activation with IL-18 or IL-15 in combination with IL-12: implications for the innate immune response. J Immunol (1999) 162(8):4511-20.

82. Fehniger TA, Cooper MA, Nuovo GJ, Cella M, Facchetti F, Colonna M, et al. CD56 $6^{\text {bright }}$ natural killer cells are present in human lymph nodes and are activated by T cell-derived IL-2: a potential new link between adaptive and innate immunity. Blood (2003) 101(8):3052-7. doi:10.1182/blood-200209-2876

83. Carson WE, Dierksheide JE, Jabbour S, Anghelina M, Bouchard P, Ku G, et al. Coadministration of interleukin-18 and interleukin-12 induces a fatal 
inflammatory response in mice: critical role of natural killer cell interferongamma production and STAT-mediated signal transduction. Blood (2000) 96(4):1465-73.

84. Smyth MJ, Swann J, Kelly JM, Cretney E, Yokoyama WM, Diefenbach A, et al. NKG2D recognition and perforin effector function mediate effective cytokine immunotherapy of cancer. J Exp Med (2004) 200(10):1325-35. doi:10.1084/ jem.20041522

85. Lauwerys BR, Renauld JC, Houssiau FA. Synergistic proliferation and activation of natural killer cells by interleukin 12 and interleukin 18. Cytokine (1999) 11(11):822-30. doi:10.1006/cyto.1999.0501

86. Fabbi M, Carbotti G, Ferrini S. Context-dependent role of IL-18 in cancer biology and counter-regulation by IL-18BP. J Leukoc Biol (2015) 97(4):665-75. doi:10.1189/jlb.5RU0714-360RR

87. Kalinski P, Giermasz A, Nakamura Y, Basse P, Storkus WJ, Kirkwood JM, et al. Helper role of NK cells during the induction of anticancer responses by dendritic cells. Mol Immunol (2005) 42(4):535-9. doi:10.1016/j. molimm.2004.07.038

88. Wong JL, Berk E, Edwards RP, Kalinski P. IL-18-primed helper NK cells collaborate with dendritic cells to promote recruitment of effector CD8 ${ }^{+}$ T cells to the tumor microenvironment. Cancer Res (2013) 73(15):4653-62. doi:10.1158/0008-5472.CAN-12-4366

89. Takeda K, Tsutsui H, Yoshimoto T, Adachi O, Yoshida N, Kishimoto T, et al. Defective NK cell activity and Th1 response in IL-18-deficient mice. Immunity (1998) 8(3):383-90. doi:10.1016/S1074-7613(00)80543-9

90. Chaix J, Tessmer MS, Hoebe K, Fuseri N, Ryffel B, Dalod M, et al. Priming of NK cells by IL-18. JImmunol (2008) 181(3):1627-31. doi:10.4049/ jimmunol.181.3.1627

91. Semino C, Angelini G, Poggi A, Rubartelli A. NK/iDC interaction results in IL-18 secretion by DCs at the synaptic cleft followed by NK cell activation and release of the DC maturation factor HMGB1. Blood (2005) 106(2):609-16. doi:10.1182/blood-2004-10-3906
92. Szabo SJ, Sullivan BM, Stemmann C, Satoskar AR, Sleckman BP, Glimcher LH. Distinct effects of T-bet in TH1 lineage commitment and IFN-gamma production in CD4 and CD8 T cells. Science (2002) 295(5553):338-42. doi:10.1126/science.1065543

93. Yu J, Wei M, Boyd Z, Lehmann EB, Trotta R, Mao H, et al. Transcriptional control of human T-BET expression: the role of Sp1. Eur J Immunol (2007) 37(9):2549-61. doi:10.1002/eji.200737088

94. Matsuda JL, George TC, Hagman J, Gapin L. Temporal dissection of T-bet functions. J Immunol (2007) 178(6):3457-65. doi:10.4049/jimmunol.178. 6.3457

95. Wang R, Jaw JJ, Stutzman NC, Zou Z, Sun PD. Natural killer cell-produced IFN-gamma and TNF-alpha induce target cell cytolysis through up-regulation of ICAM-1. J Leukoc Biol (2012) 91(2):299-309. doi:10.1189/jlb. 0611308

96. Mullen AC, High FA, Hutchins AS, Lee HW, Villarino AV, Livingston DM, et al. Role of T-bet in commitment of TH1 cells before IL-12-dependent selection. Science (2001) 292(5523):1907-10. doi:10.1126/science.1059835

97. Afkarian M, Sedy JR, Yang J, Jacobson NG, Cereb N, Yang SY, et al. T-bet is a STAT1-induced regulator of IL-12R expression in naive CD4 ${ }^{+} \mathrm{T}$ cells. Nat Immunol (2002) 3(6):549-57. doi:10.1038/ni794

Conflict of Interest Statement: The authors declare that the research was conducted in the absence of any commercial or financial relationships that could be construed as a potential conflict of interest.

Copyright $(2017$ Zwirner and Ziblat. This is an open-access article distributed under the terms of the Creative Commons Attribution License (CC BY). The use, distribution or reproduction in other forums is permitted, provided the original author(s) or licensor are credited and that the original publication in this journal is cited, in accordance with accepted academic practice. No use, distribution or reproduction is permitted which does not comply with these terms. 